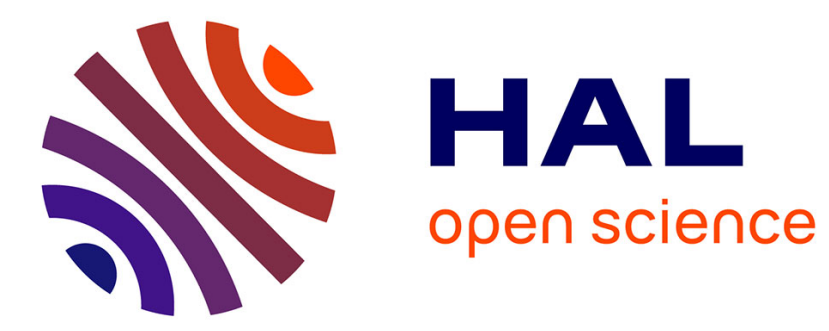

\title{
IMPROVED OPERATION OF A CW YLF LASER
}

\author{
A. Di Lieto, A. Neri, P. Minguzzi, F. Pozzi, M. Tonelli, H. Jenssen
}

\section{To cite this version:}

A. Di Lieto, A. Neri, P. Minguzzi, F. Pozzi, M. Tonelli, et al.. IMPROVED OPERATION OF A CW YLF LASER. Journal de Physique IV Proceedings, 1991, 01 (C7), pp.C7-407-C7-410. 10.1051/jp4:19917104. jpa-00250752

\section{HAL Id: jpa-00250752 https://hal.science/jpa-00250752}

Submitted on 1 Jan 1991

HAL is a multi-disciplinary open access archive for the deposit and dissemination of scientific research documents, whether they are published or not. The documents may come from teaching and research institutions in France or abroad, or from public or private research centers.
L'archive ouverte pluridisciplinaire HAL, est destinée au dépôt et à la diffusion de documents scientifiques de niveau recherche, publiés ou non, émanant des établissements d'enseignement et de recherche français ou étrangers, des laboratoires publics ou privés. 


\title{
IMPROVED OPERATION OF A CW YLF LASER
}

\author{
A. DI LIETO, A. NERI, P. MINGUZZI, F. POZZI, M. TONELLI and H.P. JENSSEN* \\ Dipartimento di Fisica dell'Università, Piazza Toricelli 2, Pisa, Italy \\ ${ }^{*}$ Center for Material Science and Engineering, M.I.T., Cambridge, MA, USA
}

\begin{abstract}
We developed a $\mathrm{cw}$ laser in the $2 \mu \mathrm{m}$ region operating at liquid-nitrogen $(77 \mathrm{~K}$ ) and at dry ice temperature $(210 \mathrm{~K})$ pumped by the $514 \mu \mathrm{m}$ line of $\mathrm{Ar}^{+}$laser. Also we observed two walenghts $(670 \mathrm{~mm}, 890 \mathrm{~mm}$ ) that are significantly correlated with laser emission.
\end{abstract}

\section{Introduction.}

The Holmium emission at $2.06 \mu \mathrm{m}$ has long been the basis for the development of efficient solid-state lasers. Laser action has been reported for different host crystals, both in pulsed and in $\mathrm{cw}$ regime; room temperature as well as $77 \mathrm{~K}$ operation has been described $/ 1-8 /$.

Recently we developed a highly efficient $\mathrm{cw}$ laser employing a LIYF 4 crystal doped with $\mathrm{Er}$. Tm and $\mathrm{Ho}$, with the purpose of obtaining a low-nolse tunable source for spectroscopic applications in the $2 \mu \mathrm{m}$ wavelength region. The main results achieved in the improvement of our laser are described in the first part of this paper whlle in the second part we studied the visible an infrared fluorescence from the higher energy levels of Ho and $\mathrm{Er}$, which are populated by upconversion processes.

The motivation of this work was to improve the understanding of the basic mechanisms of energy transfer and eventually to provide guldelines for the design of a better laser device.

\section{Experimental Apparatus.}

The LiYF 4 crystal, doped with $0.72 \mathrm{Er}, 0.072 \mathrm{Tm}$ and $0.003 \mathrm{Ho}$, is placed in a cryostat inside an astigmatically compensated resonator.

The pump light is the $514 \mathrm{~nm}$ line of an Ar laser, which is infected into the YLF resonator by a ZnSe beam splitter. The crystal is placed with its " $\mathrm{C}$ " axis parallel to both the pump and the infrared polarization.

Its dimensions are $7 \times 3.5 \mathrm{~mm}$ and it is $2.5 \mathrm{~mm}$ thick. The absorption coefficient at $514 \mathrm{~nm}$ is about $6 \mathrm{~cm}^{-1}$ (at the temperature of $77 \mathrm{~K}$ ).

The resonator has a total length of about 1 meter and a folded structure with two concave mirrors $(R=5$ and $8 \mathrm{~cm})$ and a flat output mirror, all clamped to a super-invar base to insure a good thermal and mechanical stability $/ 9 /$. The curved mirrors and the crystal are kept inside the vacuum chamber of the cryostat, which is terminated by a Brewster window. An additional side window allows the direct observation of the fluorescence from the crystal in a direction orthogonal to the laser propagation. The fluorescence at 670 or $890 \mathrm{~nm}$ is selected by a small monochromator and detected by a cooled photomultiplier with S1 spectral response. A mechanical chopper and lock-in amplifier are used for signal processing. 
Results.

In the Fig. I the best performances of the lc er are displayed for two different operating conditions.

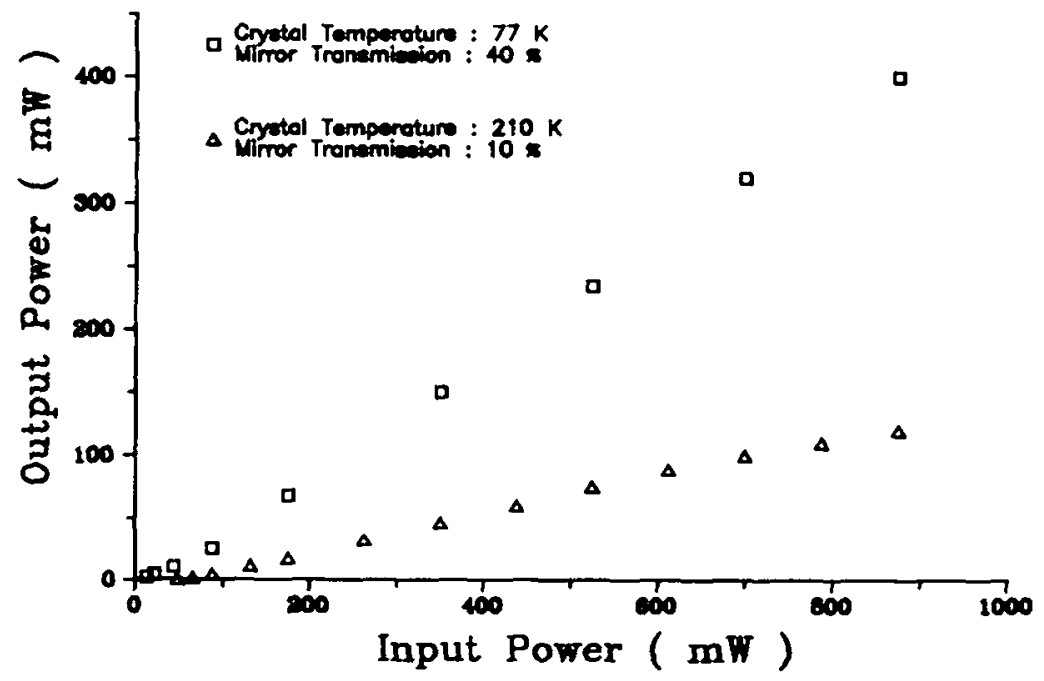

Flg.1 Maximum output power of the YLF Laser versus input power for $77 \mathrm{~K}$ and $210 \mathrm{~K}$ crystal temperature at two different transmissions of the output coupler.

The highest power is obtained with the crystal at $77 \mathrm{~K}$ and an outcoupler transmission of $40 \%$. With an incident power of $870 \mathrm{~mW}$ on the crystal, we obtained an output of $400 \mathrm{~mW}$ at $2.06 \mu \mathrm{m}$ The remarkable slope efficiency of $48 \%$ is maintained up to 3.1 Watt of incident power where an output of 1.46 Watt was observed $/ 10 \%$. We measured a pump power threshold of $15 \mathrm{~mW}$.

In the second case the crystal is operated at dry-ice temperature $(210 \mathrm{~K})$ and the optimum outcoupler transmission is $10 \%$. Now the maxdmum output power is $130 \mathrm{~mW}$. the threshold is about $60 \mathrm{~mW}$ and the slope efficiency is $15 \%$.

In Fig. 2 we plot the intensity of the irirared fluorescence at $890 \mathrm{~nm}$ as a function of pump power: a non-linear behaviour is clearly visible. :he crystal temperature is $77 \mathrm{~K}$ and laser action is inhibited by an intracavity shutter. We assign. this fuorescence to the emission from the ${ }^{5} \mathrm{I}_{5}$ level of $\mathrm{Ho}$ and the tentative explanation of non-lir sarity is given as the follows.

The Ho ${ }^{5} I_{5}$ level is populated through an upconversion process where an excited $\mathrm{Er}$ ion $\left({ }^{4} I_{13 / 2}\right)$ transfers its energy to an excited Ho $i: n\left(5_{I_{7}}\right) / 11,12 \%$. The Ho $5_{I_{5}}$ population is therefore determaned by both the Ho ${ }^{5} \mathrm{I}_{7}$ and th. $\mathrm{Er}{ }^{4} \mathrm{I}_{13 / 2}$ populations since the upconversion rate is proportional to the product of the populatirns.

A different result is shown in Fig.3: now the IR fuorescence is measured when the crystal is lasing. while all other conditions are the same as above. A linear behaviour is observed and the fluorescence has a much smaller intensity. This happens because Ho ${ }^{5} \mathrm{I}_{5}$ population is clamped to threshold by laser action. If a lower transmission is used for the outcoupler, the smaller losses will clamp the threshold population at a lower amount; . thus this modal also explatns the very small fluorescence observed at $T=5 \%$. 


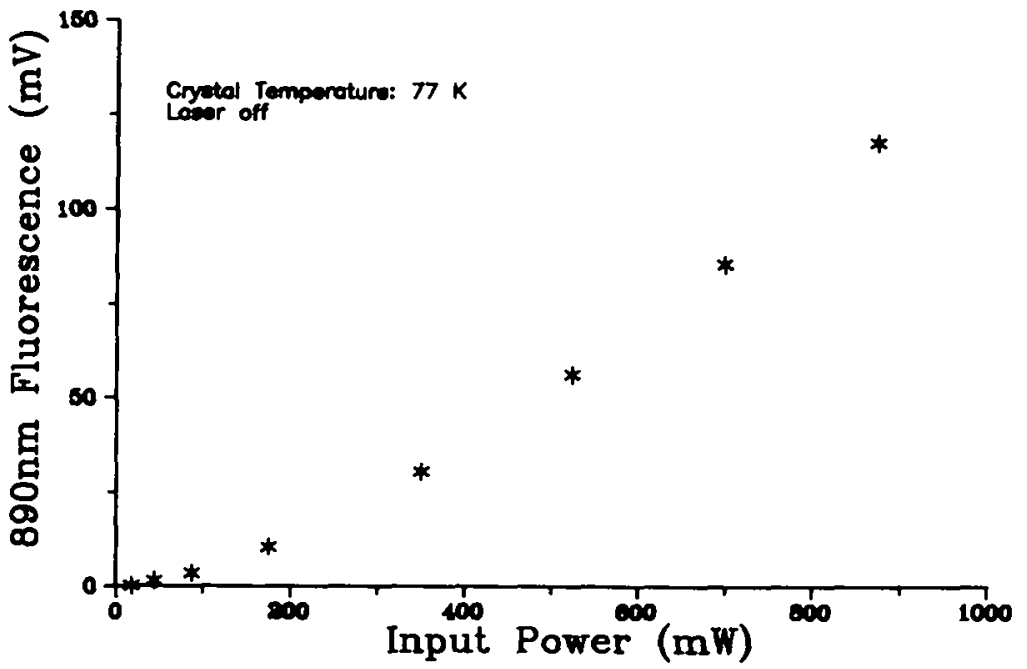

Fig.2 Intensity of the infrared fluorescence versus input power with the laser not operating

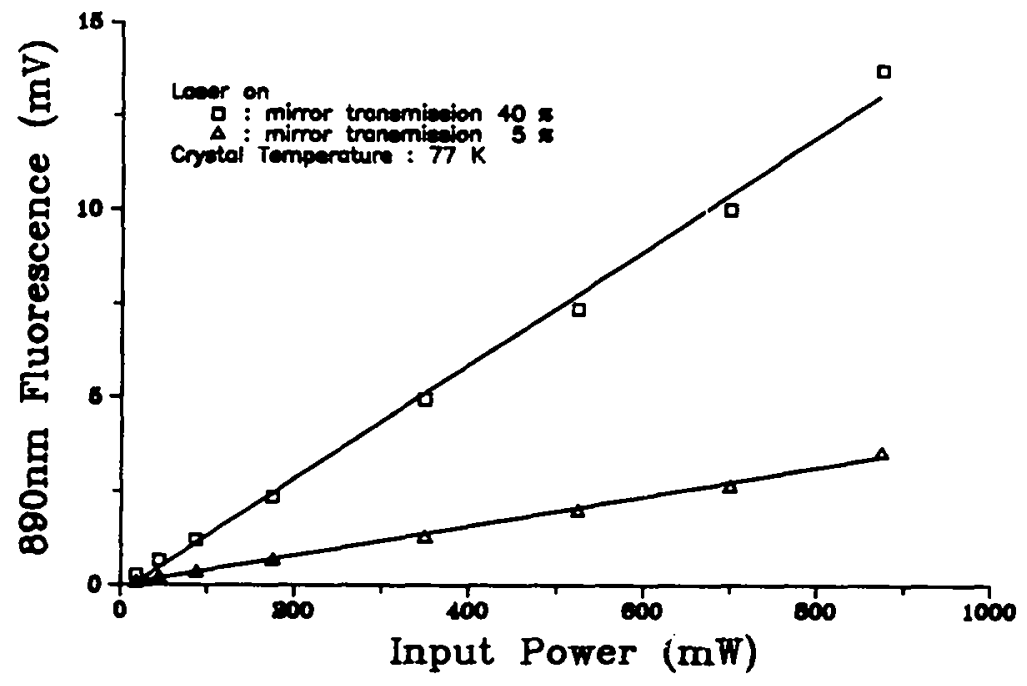

Fig.3 Intensity of the infrared fluorescence versus input power with the laser operating at two different transmissions of the output coupler 
We studied a second fluorescence line in the visible, at $670 \mathrm{~nm}$ and here too we compared lasing and non-lasing intensittes. This emission can be assigned either to the Ho ${ }^{5} \mathrm{~F}_{5}$ or the $\mathrm{Er}$ ${ }^{4} \mathrm{I}_{9 / 2}$ levels which are almost exactly resonant.

The most likely process is where one excited $\mathrm{Er}$ ion in ${ }^{4} \mathrm{I}_{11 / 2}$ combines with one excited Ho ion in ${ }^{5} \mathrm{I}_{7}$ resulting in one excited $\mathrm{Er}$ ion in ${ }^{4} \mathrm{~F}_{9 / 2}$ or one excited Ho ion in ${ }^{5} \mathrm{~F}_{5}$. In this case too we found that the fluorescence is remarkably increased when laser action is inhibited, a behaviour similar to that of the infrared fluorescence. Since upconversion presents a loss for the laser and since $\mathrm{Er}$ is identified as being responsible for both of the processes, the $2.06 \mu \mathrm{m}$ laser should work better when only $\mathrm{Tm}$ is used as a sensitizer. This is possible when laser diodes are used for pumping.

As a conclusion we can state that we have obtained a powerful and stable laser source in the $2 \mu \mathrm{m}$ region and we have reported a preliminary study of the connections between crystal fluorescence and laser action.

\section{References.}

/1/ Jhonson, L.F., Gensic, J.E., Van Uitert, L.G., Appl. Phys. lett 7 (1965) 127.

12/ Remsk1, R.L., James, L.T., Gooen, K.H., DI Bartolo, B., LInz, A., IEEE J. Quantum Electr. QE-5 (1969) 214.

/3/ Chicklis, E.P., Naiman, C.S., Folweiler, R.C., Gabbe, D.R., Jenssen, H.P., Linz, A., Appl. Phys. lett. 19 (1971) 119.

14/ Hosklns, R.H., Soffer, B.H., IEEE J. Quantum Electr. QE-2 (1966) 253.

15/ Smirnov, V.A., Shcherbakov, F.A., IEEE J. Quantum Electr. QE-24 (1988) 949.

16/ Huber, G.. Duczynsk. E.W., Petermann, K., IEEE J. Quantum Electr. QE-24 (1988) 920.

17/ Fan, T.Y.. Huber. G., Byer, R.L., R.L.. Mitzscherlich P., IEEE J. Quantum Electr. QE-24 (1988) 924.

18/ Esterowitz, L., Allen, R. Goldberg, L., Weller, J.F., Storm, M., Abella, I., in "Tunable solldstate laser II" A.B. Budgord et al. editors (Berlin 1986) pag. 291.

19/ Di Lleto. A., Minguzz1, P.. Pozz1, F., Tonell, M., Jenssen. H.P.. Optical Soc. of America Proceedings vol.5, M.L. Shand et al. editors (New York 1989) pag. 227.

/10/ Di Lieto, A., Minguzzi, P., Neri, A., Pozzi, F., Tonelli, M., Jenssen, H.P., in "Advanced Solid State lasers" Optical Soc. of America, in press, 1991.

111/ Chou, H., Jenssen, H.P. In "Tunable Solid State lasers" Optica! Soc. of America Proceedings vol.5, M.L. Shand et al. editors (New York 1989) pag. 167.

/12/ Auzel, F.E., Proc. of IEEE 61 (1973) 758. 